\title{
TURN-TAKING STRATEGIES USED IN A NEW ZEALAND RADIO INTERVIEW PROGRAMME AND PEDAGOGICAL IMPLICATIONS IN LANGUAGE CLASSROOMS
}

\author{
Cao Thi Hong Phuong* ${ }^{* 1}$ Pham Xuan Tho ${ }^{2}$ \\ 1. Victoria University of Wellington, New Zealand \\ Kelburn, Wellington 6012, New Zealand \\ and Hanoi National University of Education, Vietnam \\ 136 Xuan Thuy Street, Cau Giay District, Hanoi, Vietnam \\ 2. VNU University of Languages and International Studies, \\ Pham Van Dong, Cau Giay, Hanoi, Vietnam \\ Received 5 January 2019 \\ Revised 7 June 2019; Accepted 22 December 2019
}

\begin{abstract}
The present paper analyses conversational strategies employed by the interviewer on a New Zealand radio programme from conversation analysis (CA) perspective. This study employs a documentary method of interpretation in order to seek answer(s) to the research question. Specifically, Sacks, Schegloff and Jefferson's (1974) model of conversation analysis was adopted to explore turn-taking strategies used in the interview. The analysis reveals that the interviewer employed a variety of turn-taking strategies such as signaling the end of turn, holding a turn, asking a question, self-selection and "prosodic features" (ibid.) to achieve the purpose of the interview. The findings of this study suggest several potential CA-informed pedagogical implications for English language teaching classroom.

Keywords: conversation analysis, turn-taking strategies, pedagogical implications, English Language Teaching

\section{Introduction}

Conversations are highly organized in relation to both sequence organization and turn-taking (Seedhouse, 2006). With reference to the former, conversations can be categorized into three stages of sequence namely pre-sequence, main sequence, and closing sequence. In relation to the latter, it refers to the conversational strategies and languages used by speakers to construct and allocate turns.

Pomerantz and Fehr (1997) also asserted that the context of the conversation could

* Corresponding author. Tel.: 64-225135952,

profoundly affect the conduct produced by interactants. As reflected in the audio and transcription (see the Appendix), a conversation fragment extracted from a radio interview between Kim Hill and Graeme Aitken has been analyzed. Kim Hill is interviewing Professor Graeme Aitken on his retirement as Dean of Education at the University of Auckland (henceforth KH and GA). The interview's purpose is to explore GA's viewpoints on the success of the NGATAHI education initiative program in New Zealand. The analysis of the conversation shows that the utterances mostly come in adjacency pairs of questions and answers which initiate exchanges and are responsive to the action of a prior turn
\end{abstract}

Email:phuong.cao@vuw.ac.nz 
(Schegloff, 2007). However, this paper only focuses on the exploration of the interviewer's talk. Specifically, the paper analyses the turntaking strategies used by $\mathrm{KH}$ in order to dominate the conversation, to keep it going, and to achieve the purpose of the interview. The paper then discusses several pedagogical implications for language classroom use.

With regard to the English language teaching and learning in Vietnam, there has been a language teaching reform project: to improve the situation through the current educational initiative known as the National Foreign Languages Project (NFL). As part of this language project, university students are required to function successfully at B1 according to the Common European Framework of Reference for languages (CEFR) before they graduate. To respond to this reform, English educators, lecturers, and instructors have sought ways to improve the quality of language teaching and learning (Nguyen \& Cao, 2019), one of which is to apply CA-informed materials and knowledge for more effective classroom instruction. This is the primary reason why we have chosen to analyze a radio interview.

\section{Research question}

The present study aims to seek answer(s) to the following research question: What turn-taking strategies are employed by the interviewer to achieve the interview's purpose?

\section{Theoretical background}

In this section, the authors briefly present some theoretical backgrounds of CA, turntaking and turn-taking strategies. The authors then discuss the possible use of turn-taking strategies in the realm of language teaching such as turn-taking organization, turn design and sequence organization in classroom interaction. It is argued that these strategies enhance students' participation in classroom activities and make language teaching and learning more effective.

$\mathrm{CA}$ as an approach in social interactions and talk-in-interactions research has exerted substantial impacts across the humanities and social sciences including linguistics in general and language teaching in particular. It is mainly concerned with how turn-taking is achieved and how interactants take their turns during their conversations (Hutchby \& Wooffitt, 2008). These authors state that three fundamental facts about a conversation are (1) the occurrence of turn-taking; (2) one speaker tends to talk at a time; (3) there are little gaps or overlaps between speakers. In $\mathrm{CA}$, any conversations can be researched (Pomerantz \& Fehr, 1997), for instance, chats among acquaintances, interactions between teachers and students, job interviews, broadcast commentaries, political speeches to name just a few. In a second language (L2) learning classroom, learners may benefit from instructions with CA-based materials so that they can anticipate, interpret and produce the target language sociopragmatically and correctly. Based on empirical evidence, Huth \& Taleghani-Nikazm (2006) argue that CAbased materials can provide in-depth resources for language teachers and effectively allow L2 learners to engage in cross-culturally variable language conducts inside and outside classrooms.

\section{Turn-taking and Turn-taking Strategies}

Turn-taking refers to the basic principles in conversations, in which one person speaks at a time, after which this person may nominate another interactant, or another speaker may take up the turn without being nominated (Sacks, Schegloff \& Jefferson, 
1974; Sacks, 2004, Gardner, 2013). Turntaking helps maintain the conversation's flows by allowing interactants to take the floor in order to contribute to the conversations. There are numerous ways in which speakers can achieve the purposes of conversations: by signaling that they have come to the end of a turn or signaling a new turn. This may be at the time they complete a syntactic unit, or it may be via speakers' use of falling intonation or language functions (Paltridge, 2012). According to Clark and Tree (2002), speakers may also begin a turn at talk without having fully planned their turn, they take turn by using filled pauses (e.g., "uh," “um”), meaning "signaling a turn" at the beginning of their turn in order to "buffer" their comprehension or planning (Clark \& Tree, 2002, p. 120). Sacks, Schegloff and Jefferson (1974) also presented a model of turn-taking strategies in social interaction by outlining how this behavior constitutes a system of social interaction with specific properties. Sacks et al. (1974) claimed that the most familiar turn-taking pattern is the selection of the next interlocutor by the current interlocutor (e.g. signaling the end of turn, holding a turn, asking a question, gazing towards a particular person, addressing other parties by name, self-selection and "prosodic features". It means that the speaker's choice of language and intonation that allow at least two parties to achieve the conversations. Reviewing several frameworks of turntaking strategies such as Sacks, Schegloff and Jefferson (1974), Sacks (2004), Paltridge (2012), Clark and Tree (2002), the authors have decided to adopt Sacks, Schegloff and Jefferson's (1974) model because when we analyzed the data, we realized that most turn-taking strategies in Sacks, Schegloff and Jefferson (1974) found in the recorded interview. Additionally, this framework is relevant to conversation analysis of various socially organized activities including interview, as this model covers the simplest systematics for the organization of turntaking for conversation (Sacks, Schegloff \& Jefferson, 1974, p. 696)

\section{Turn-taking Strategies in the Language Classroom}

Tsui (2001) argued that the central features of classroom interaction are turn exchanges of teacher-learners' conversations and students themselves. To be more specific, learners' turn-taking and teacher's turn-allocations help create opportunities for learners to participate in language classroom interaction. For instance, teachers can facilitate learnercentered pedagogies by establishing a set of turn-taking rules for the students. It is evidenced by McHoul's (1978) research on classroom use of turn-taking rules, which allow teachers to select a learner to take a turn to speak and this student must select another student as a next speaker. Thus, by taking turns, students' linguistic resources are required to produce utterances to achieve transitions. Seedhouse (2004a) also suggested using turn-taking strategies among group work in task-based language teaching (TBLT) classrooms, where students can manage turn-taking by themselves (self-selection), contributes to the increase in students' interaction in the target language. This is confirmed by Willis and Willis (2007), which emphasized that social interaction among participants in group work's activities of coconstruct tasks and turn-taking system could afford opportunities for language learning to occur. Reflecting on the Vietnamese tertiary EFL settings, the authors argue that the use of turn-taking practices can be applied in this context through different ways to enhance the quality of teaching and learning. Teachers can exploit turn-taking strategies such as 
signaling a turn, prosodic features, and asking questions in speaking lessons, in group work discussions and TBLT settings to boost the effectiveness of classroom interaction.

\section{Sequence organization and the design of turns}

Teachers' relevant exploitation of the sequential organization and the allocations of turns such as holding a turn, signaling a turn, and asking a question in language classrooms may help facilitate learning. For example, Lee (2007) argued that when teachers withhold the sequence of third-turn completion, students may realize that another response is required. Therefore, the extension of the sequence is produced. Similarly, potential values of Initiation-Response-Evaluation (IRE) in improving students' participation are also confirmed in recent studies (e.g. Lin, 2000; Mondada \& Doehler, 2004). These authors asserted that in both traditional and TBLT oriented classrooms, expanded turns can be performed by students and teachers as a facilitator to different learning opportunities. Moreover, the potential benefits of InitiationResponse-Feedback (IRF) have also been realized in a wealth of research (Hutchby \& Wooffit, 2008; Liddicoat, 2007; Sullivan, 2000). For instance, a study in the EFL tertiary classroom in Vietnam, Sullivan (2000) concluded that students' participation could be nurtured through teachers' use of affirmations, elaborations, and follow-ups on students' responses. This author also argued that the networks of interaction among students could also be established and promoted by the exploitation of students' humorous words and ideas. This playful interaction, in turn, leads to a more close-knit relationship among participants. Thus, they can be more motivated to keep them extensively participated in meaning-focused interaction as language learners. As reflected, sequence organization and the design of turns have been proven to play a crucial role in helping create and maintain learners' interaction in the EFL Vietnamese classrooms at the university level.

\section{Methodology}

The data has been collected and analyzed in order to seek answer(s) to the following research question: "What turn-taking strategies are employed by the interviewer to achieve the interview's purpose?"

The data is in the form of a recorded interview from a New Zealand radio programme. This interview was ten minutes long and was broadcast live. The second author transcribed the recording. The first author then cross-checked the transcription after which discrepancies were discussed before the draft of transcription was finalized. The authors then employed a documentary method of interpretation in order to explain the interview from the perspective of CA. After that, the authors performed a datadriven analysis in order to identify if there were any recurring patterns of interaction. In particular, the authors' focus was on the documentary method of interpretation. As Seedhouse (2004b, p.7) put it, "the documentary method of interpretation is central to ethnomethodology" which treats any actual real-world action as a "document" (ibid.). It means that we treat transcripts as major documents to be analyzed and interpreted. The transcription symbols in this paper are commonly used in conversation analytic research and were developed by Jefferson (1996). The data was interpreted using Sacks, Schegloff and Jefferson's (1974) framework on conversation analysis to form a description of how turn-taking was utilized in the interview. The authors' analytical claims are supported by excerpts drawn from the data and draw on the existing literature to further back up the findings. 


\section{Findings and Discussions}

According to Seedhouse (2006, p. 166), the ways interactants analyzed and interpreted each other's actions might "develop a shared understanding" of the progress of the conversation, which allowed them to achieve the conversation organization and order. In this section, turn-taking strategies adopted by the interviewer will be analyzed and discussed in order to shed light on how the interview was achieved. In other words, the interviewer used a number of turn-taking strategies such as signaling a turn, holding a turn, prosodic features, asking questions and signaling the end of a turn in order to accomplish her role as an interviewer. It means that, with the use of strategies, choice of languages and intonation, $\mathrm{KH}$ was successful in the role of an interviewer in a radio interview programme. These aforementioned strategies will be discussed in this section from the perspective of CA.

As argued by Hutchby and Wooffitt (2008), central characteristics of turn-taking are reflected through speakers' organizations of talk; the linguistic and non-linguistic resources are used to perform the utterances. In relation to KH's turn-taking strategies and language use; the recurring patterns take place seven times in the extract, and they are taken mostly with overlap. Accordingly, the interviewer also used various language functions such as inviting, steering, navigating, agreeing and acknowledging tokens to accomplish her role.

The excerpt (1) below refers to the first turn taking made by $\mathrm{KH}$, which provides a preparatory foundation setting up status (Heritage, 2013) for the incoming actions of the interviewer.

\section{Excerpt (1)}

$\mathrm{KH}->$ It it it (0.5) sounds like a no-brainer I mean obviously education can break its generational cycle of poverty. hh> why why< (0.5) isn't that taken more seriously by: the people who put money into the system.> do you know what I mean $<$ we we $(0.5)$ constantly talk about $(0.1)$ early intervention we constantly talk about education being the key: is it THAT $\uparrow(0.5)$ is it (0.5) THAT $\uparrow \mathrm{hm}$ $(0.5)$ the people in charge: don't really believe that $\downarrow$ or [they do?

\section{GA ->Na I [think they]}

KH's questions introduced with a declarative statement in the excerpt (1) can also provide background information "establishing the relevance of ensuring questions" (Clayman, 2012, p. 631). It is clear that $\mathrm{KH}$ asked GA in different ways, establishing a mutual understanding of the situation and the relevance of the questions. She also used the question "Do you know what I mean" with little space, assuming that GA had already interpreted the meanings. She went on to ask "is it THAT?" with a little pause of 0.5 seconds. Then she repeated the utterance "is it THAT?" to emphasize the situation of whether or not people in charge believe in the role of education as the key to supporting children in their education and life success. In other words, she took a turn to pursue a response and confirmation from GA and establish the relevance of the questions by paraphrasing them many times. In summary, KH's strategies are in line with Sacks, Schegloff and Jefferson's (1974) use of "signaling a turn" and "asking a question" in order to invite a response from another interlocutor.

The excerpt (2) below refers to her second turn-taking, which shows an overlap. This taking turn may act as a "recognitional onset" (Hutchby \& Wooffitt, 2008). Probably, when KH identified what GA was talking about, she could project the completion of the talk uttering "they do" and then led up to the next question to avoid disorientation.

\section{Excerpt (2)}


KH -> [They do no no no I mean I'm wondering why it has to be reargued every time $\downarrow$

GA -> I think they really believe it uh (0.5) what I'm not sure is that they put the money into the right place I I (0.5) spoke ( (a little bit)) earlier about the three things that matter in education? and I think we've overemphasized one of them to the expense of the other. We've over-emphasized achievement and success, and measuring achievement and success at the expense of what I think matters even more than that and that's engaging young people in something that fascinates and interests them [and]

The third turn is taken by $\mathrm{KH}$ (excerpt 3) with a little overlap between the two speakers. When GA still uttered "and" KH took a turn by asking "what is the difference?" in order to clarify GA's ideas of measuring students' achievement and engaging them in something that fascinates them. In relation to Sacks, Schegloff and Jefferson's (1974) turn-taking strategies, KH mostly employed "prosodic features" and "asking a question", so that GA could further contribute to the conversation.

\section{Excerpt (3)}

KH $->$ [what's the difference? because one would imagine that if you engage them in something that fascinates and interests (0.5) them that will translate into achievement and [success]

GA-> [Absolutely but that's the way to work I I (0.5) agree completely. That we need to start with fascination and interest and lead to achievement uh (0.5) not have our system driven by uh (0.5) achievement and [achievement measures

It can be inferred that $\mathrm{KH}$ was able to recognize the incoming utterances made by GA. She navigated the focus of the conversation by raising her voice when asking "what the difference?" showing the power of an interviewer to take turns. If she was to wait for GA to stop talking, he might continue with another unit. According to Hutchby and Wooffitt (2008), this reason may be a "possibility of completion" rather than an interruption. According to Schegloff and Jefferson's (1974) turn-taking strategies, this can be referred to as "prosodic features" and "holding a turn". Thus this transitional onset seems to be relevant in keeping the conversation going appropriately.

The forth turn-taking time by $\mathrm{KH}$ referred to the excerpt four bellows when she uttered: "I see". She probably expressed a sign of agreement with what GA had stated previously. This means that she had already interpreted what GA meant by how engaging young people in fascination and interest could lead to achievement.

\section{Excerpt (4)}

$\mathrm{KH}$-> [I see so by concentrating too much on: MEASURING we are LEACHING things of their fascination is that [what you mean]

GA-> [I'm sure about that and if I think back in 40 years in education, the opportunities I had as a teacher in the 1970 s and 80 s just to pursue: my own, and students' interests were just far greater ((than it is)) now. hh

She further summed up GA's ideas by emphasizing the word "on" as a signal of the two factors "measuring, leaching" mentioned later. She also confirmed her interpretation by asking "is that what you mean, so that GA could carry on his flow of talk.

The following excerpt contains KH's next turn-taking, which shows a sign of invitation. By saying "yes," KH meant to invite GA to 
have a further talk. This sign of invitation enables GA, as stated by Huth and TaleghaniNikazm (2006) to interpret the current conversational action in order to project the relevant ongoing contribution. This strategy is in line with what Sacks, Schegloff and Jefferson (1974) considered a signal to end her turn and self-selection in order to invite GA to answer her question.

\section{Excerpt (5)}

KH-> [You were yes] $\downarrow$

GA-> [And I emphasize my own interests because the other thing I think is is missing in this space is the affirmation for teachers actually to be leaders in the classroom and to take. curious young minds into all sorts of places they might not have thought of going and (0.5) the notion that teachers somehow: simply facilitate students' current interests (0.1) to me downplays and (0.5) in a way lowers the status of teaching. Teachers I think have got a wonderful opportunity. uh (0.5) to lead young minds into places they've never ever thought of going before, and (0.1) that's what I loved about teaching

The excerpt 6 below refers to KH's sixth and seventh turn-taking time, which seems to act as an evaluation and a pursuit of an agreement rather than a question. The utterance " already" with a falling intonation may indicate a signal of evaluating and acknowledging the prior discussions. Similarly, the last turn-taking also refers to the pursuit of an agreement. Both these turn-taking times seem to seek a kind of "yes" answer. This, according to (Hutchby \& Wooffitt, 2008), indicates a preference, which intentionally invites GA to response to a straightforward agreement without gaps. In relation to Sacks, Schegloff and Jefferson's (1974) turn-taking strategies, this may be considered as "prosodic features" when she said " already" with a falling intonation to seek GA's answer.

\section{Excerpt (6)}

KH-> That does seem odd doesn't it THAT we focus on what $(0.5)$ they're interested in already $\downarrow$

$$
\text { GA-> Yeah } \downarrow
$$

$\mathrm{KH}->$ As if nothing's ever going to [change]

GA-> [Exactly (0.5) that's exactly it and I find GA-> that so frustrating we talk about ourselves being facilitators and guides um (0.5) which itself, I think just downgrades the value of that wonderful word teacher. teacher as a leader, so the leader of young minds $\downarrow$

In terms of the number of times a strategy is employed within this interview, we can see that 'asking a question' strategy occurs in five instances, 'self-selection' also happens the same number of times. This is followed by 'holding a turn' strategy which is employed four times while 'prosodic features' can be identified the same number of times as the 'signaling the end of turn' (three instances each). Thus, we can conclude that KH's strategies of turn-taking such as 'signaling the end of turn', 'holding a turn', 'asking a question', 'self-selection' and 'prosodic features' seem to play a significant part in controlling the focus of the interview.

These findings are in line with the existing body of knowledge on turn-taking strategies as they are used in conversations in different social contexts. In other words, the findings of this paper further confirm the previous studies (see, for example, Sacks, Schegloff and Jefferson,1974; Sullivan, 2000; Sacks, 2004; Clark and Tree, 2002; Weilhammer \& Rabold, 2003; Liddicoat, 2007; Hellermann, 2008; 
Hutchby \& Wooffit, 2008; Paltridge, 2012; Martin-Jones, 2015) which conclude that turn-taking strategies play an important role in the success of conversations in general, and language teaching classroom conversations in particular (Hall \& Walsh, 2002; Hellermann, 2008). The accomplishment of the speaker's goals is substantially dependent on the ways they employ turn-taking strategies. This is also in agreement with another study (Üstünel \& Seedhouse 2005) which argues that turntaking strategies and use of language can facilitate conversations including those which take part in L2 teaching and learning environments (Üstünel \& Seedhouse 2005). The findings also support the existing evidence on the efficacy of using conversation analysis as a teaching strategy in the L2 classroom (Clark and Tree, 2002; Weilhammer \& Rabold, 2003; Seedhouse, 2004a; MartinJones, 2015). Specifically, Seedhouse (2004a) provided different instances of turn-taking strategies used by language teachers for teaching form and accuracy. He emphasized that these strategies could be used in meaningand-fluency contexts to establish mutual understanding and to negotiate meaning. After an in-depth analysis of different chunks of the interview, the authors confirm that turntaking strategies could enable L2 learners to produce specific sequences of linguistic forms and help them negotiate meanings and thus avoid breakdowns in communication.

\section{Pedagogical Implications}

It is well acknowledged that turn-taking as a pedagogical approach is at the core of teaching and learning in any subject including learning a language (Nomlomo, 2010; Martin-Jones, 2015). It consists of instructional and regulative components as it considers what kind of knowledge needs to be exchanged and how the knowledge should be transmitted. From a language teachers' perspective, authentic materials can be useful for language learners as the prime use of language may involve rapid switching between comprehension and production at a rate, which implies that these processes sometimes overlap. Reflecting on our teaching experience and situations, learners may only be exposed to the conversations of the nogap-no-overlap from commercial textbooks and "ideal" teaching materials. Therefore, an authentic material may suggest that real-life conversations can be successfully achieved with strategies including turn-taking strategies. In other words, through the use of turn-taking strategies, speakers can hold a conversation to make it successful. Thus, turntaking strategies used in any conversations of social interaction can be informed for language classroom teachers to adopt in their contexts.

In relation to the Vietnamese tertiary setting, an objective of the NFL is to enable university students to become effective English language users who can communicate successfully in different environments (Le, 2008). Thus, the role of Vietnamese teachers of English is to bring students chances to engage in language classroom interaction. We argue that teachers can apply the CAinformed pedagogical approach including turn-taking strategies to classroom practices to improve the English learning and teaching situation. To be more exact, teachers may choose to utilize strategies from this interview namely signaling an end of turn, holding a turn, asking a question, self-selection and "prosodic features" in speaking lessons for both students and instructors, so that students can benefit from these strategies to improve their language proficiency.

Teachers may also establish sets of turntaking rules for the students in English speaking lessons. For example, teachers can select a learner to take a turn to speak and this student must select another student to take the next speaking turn. Another potential implication 
of turn-taking strategies is teachers' use of feedback as affirmations, elaborations, and follow-ups on students' responses. Teachers can also introduce how people use turn-taking strategies in authentic real-life conversations such as inviting, steering, navigating, agreeing and acknowledging utterances to achieve their goals. Pedagogically, the findings from this study begin to address teachers' practical concerns with regard to the application of turn-taking strategies to ensure learners' participation in a language classroom.

\section{Conclusion and Limitations of the Study}

The findings of the study show five most frequent turn-taking strategies used by the interviewer: signaling end of turn, holding a turn, asking a question, self-selection and "prosodic features". Although these turntaking strategies are found in an interview, they can also be recommended to adopt in language classroom in a numerous ways discussed earlier. Through the analysis of this conversation, we argue that KH's use of turntaking strategies helps support her to succeed in the role of an interviewer, we also present some pedagogical implications that language teachers can exploit in language classroom use. We would conclude the paper by referring to Wong (2002), which mentioned that language teachers should develop a more in-depth insight into systematic practices that conversations naturally take place. Therefore, English teachers can further apply these aspects to language classroom instruction in order to maximize the effectiveness of language teaching and learning.

One limitation of the present paper should be noted when considering the results. In this study, only the interviewer's turn-taking strategies were analyzed, and the interviewee's data were omitted. Therefore, the findings cannot represent the whole picture of the success of the conversation.

\section{References}

Clark, H. H., \& Tree, J. E. F. (2002). Using uh and um in spontaneous speaking. Cognition, 84(1), 73-111.

Clayman, S. E. (2012). Conversation Analysis in the News Interview. The Handbook of Conversation Analysis, 630-56.

Gardner, R. (2013). Conversation Analysis in the Classroom. The Handbook of Conversation Analysis, 593-611.

Hall, J. K., \& Walsh, M. (2002). 10. Teacher-student Interaction and Language Learning. Annual Review of Applied Linguistics, 22, 186.

Hellermann, J. (2008). Social Actions for Classroom Language Learning. Clevedon: Multilingual Matters.

Heritage, J. (2013). Epistemics in conversation. The Handbook of Conversation Analysis, 370-94.

Hutchby, I., \& Wooffitt, R. (2008). Conversation analysis (2nd ed). Cambridge, UK.

Huth, T., \& Taleghani-Nikazm, C. (2006). How can insights from conversation analysis be directly applied to teaching L2 pragmatics? Language Teaching Research, 10(1), 53-79. https://doi. org/10.1191/13621688061r184oa

Jefferson, G. (1996). A case of transcriptional stereotyping. Journal of pragmatics, 26(2), 159-170.

Lee, Y. A. (2007). Third turn position in teacher talk: Contingency and the work of teaching. Journal of Pragmatics, 39(6), 1204-1230.

Le, V. C. (2008). Teachers' beliefs about curricular innovation in Vietnam: A preliminary study. In Y. H. Choi \& B. Spolsky (Eds.), ELT Curriculum Innovation and Implementation in Asia (pp. 191216). Seoul: Asia TEFL.

Liddicoat, A. (2007). An Introduction to Conversational Analysis. London: Continuum.

Lin, A. M. Y. (2000). Lively children trapped in an island of disadvantage: the Verbal play of Cantonese working-class schoolboys in Hong Kong context. International Journal of Sociology of Language, 143(1), 63-84.

Martin-Jones, M. (2015). Multilingual classroom discourse as a window on wider social, political and ideological processes. The handbook of classroom discourse and interaction, 446-460.

McHoul, A. (1978). The organization of turns at a formal talk in the classroom. Language in society, 7(2), 183-213.

Mondada, L., \& Doehler, S. P. (2004). Second language acquisition as situated practice: Task accomplishment in the French second language classroom. The Modern Language Journal, 88(4), 501-518.

Nguyen, T. T. M., \& Cao, T. H. P. (2019). An evaluation of the intercultural orientation of secondary English 
textbooks in Vietnam: How well are students prepared to communicate in global contexts? In Building Teacher Capacity in English Language Teaching in Vietnam (pp. 150-165). Routledge.

Nomlomo, V. (2010). Classroom interaction: Turntaking as a pedagogical strategy. Per Linguam: a Journal of Language Learning (Per Linguam: Tydskrif vir Taalaanleer), 26(2), 50-66.

Paltridge, B. (2012). Discourse analysis: An introduction. Bloomsbury Publishing.

Pomerantz, A., \& Fehr, B. J. (1997). Conversation analysis: An approach to the study of social action assense-making practices. Discourse as social interaction, 2, 64-91.

Sacks, H. (2004). An initial characterization of the organization of speaker turn-taking in conversation. Pragmatics and beyond new series, 125, 35-42.

Sacks, H., Schegloff, E. A., \& Jefferson, G. (1974). The simplest systematics for the organization of turntaking for conversations. Language, 50(4), 696-735.

Schegloff, E. A. (2000). Overlapping talk and the organization of turn-taking for conversation. Language in society, 29(1), 1-63.

Schegloff, E. A. (2007). Sequence organization in interaction: Volume 1: A primer in conversation analysis (Vol. 1). CUP.

Seedhouse, P. (2006). Conversation Analysis and language learning. Language Teaching, 38(04),165-187. https://doi.org/10.1017/S0261444805003010
Seedhouse, P. (2004a). The international architecture of the language classroom: A conversation analysis perspective. Blackwell Publishing.

Seedhouse, P. (2004b). Conversation analysis methodology. Language Learning, 54(S1), 1-54.

Sullivan, P. (2000). Spoken artistry: Performance in a foreign language classroom. in JK Hall and LS Verplaetse (eds): Second and Foreign Language Learning through Classroom Interacting. Cambridge, UK: CUP.

Tsui, A. B. (2001). Classroom interaction. In R. Carter, \& D. Nunan (Eds.), The Cambridge guide to teaching English to speakers of other languages. Cambridge, UK: CUP.

Üstünel, E. and Seedhouse, P. (2005). Why that, in that language, right now? Code-switching and pedagogical focus. International Journal of Applied Linguistics, 15(3), 302-325.

Weilhammer, K., \& Rabold, S. (2003). Durational aspects in turn-taking. In Proceedings of the International Conference of Phonetic Sciences. Barcelona, Spain.

Willis, D. \& Willis, J. (2007). Doing Task-Based Teaching. Oxford: CUP.

Wong, J. (2002). Applying conversation analysis in applied linguistics: Evaluating dialogue in English as a second language textbook. IRAL - International Review of Applied Linguistics in Language Teaching, 40(1). https://doi.org/10.1515/iral.2002.003 


\title{
CÁCH SỬ DỤNG CHIẾN LƯợC LƯợT LÒII TRONG CHƯO'NG TRÌNH PHỎNG VẤN PHÁT THANH CÜA NEW ZEALAND VÀ Ý NGHĨA TRONG VIỆC GIẢNG DẠY TIẾNG ANH
}

\author{
Cao Thị Hồng Phương ${ }^{1}$, Phạm Xuân Thọ² \\ 1. Truòng Đại họ Victoria, Wellington, New Zealand \\ Kelburn, Wellington 6012, New Zealand Và Truoòng Đại học Su Phạm Hà Nội \\ 136 Xuân Thủy, Cầu Giấy, Hà Nội, Việt Nam \\ 2. Truoòng Đại hoc Ngoại ngũu, ĐHQGHN \\ Phạm Văn Đồng, Cầu Giấy, Hà Nội, Việt Nam
}

Tóm tắt: Bài báo phân tích chiến lược lượt lời được áp dụng trong chương trình phỏng vấn trên đài phát thanh New Zealand thông qua phương diện phân tích hội thoại. Để tìm ra câu trả lời, nghiên cứu này sử dụng phương pháp phân tích tài liệu. Cụ thể là, mô hình phân tích hội thoại của Sacks, Schegloff và Jefferson (1974) được áp dụng để xác định những chiến lược lượt lời được sử dụng trong cuộc phỏng vấn. Nghiên cứu phân tích chỉ ra rằng người phỏng vấn đã áp dùng rất nhiều chiến lược luợt lời khác nhau bao gồm: báo hiệu kết thúc lượt lời, giữ lượt lời, đặt câu hỏi, tự chọn lượt lời, cũng như cách thức lựa chọn ngôn ngữ và giọng điệu để đạt được mục đích của cuộc phỏng vấn. Từ kết quả nghiên cứu, các tác giả trình bày một số đề xuất nhằm vận dụng kiến thức phân tích hội thoại vào việc giảng dạy và học tiếng Anh.

Từ khoá: phân tích hội thoại, chiến lược lượt lời; ý nghĩa đối với việc dạy và học tiếng Anh 


\section{APPENDIX}

\section{This conversation fragment is extracted from an interview between Kim Hill and Graeme} Aitken on a New Zealand radio program broadcast worldwide

The (0.5) idea in actual fact is that you support young people, we've appointed (0.5) uh we've appointed uh (0.5) people called NAVIGATOR? uh (0.5) who who (0.5) support young people from the age (0.5) of 5 or 6 right through to (0.5) um years after schooling so they follow them for 12 to 15 years, and they stay with them for 12 to 15 years now that's an enormous commitment .hh um (0.5) but it is a commitment of support that um um (0.5) that certainly ((has been demonstrated to)) make a difference to young peoples' educational and life success

$\rightarrow \quad$ It it it (0.5) sounds like a no-brainer I mean obviously education can break its generational cycle of poverty. $h \mathrm{~h}>$ why why $<(0.5)$ isn't that taken more seriously by: the people who put money into the system. $>$ do you know what I mean $<$ we we $(0.5)$ constantly talk about (0.1) early intervention we constantly talk about education being the key: is it THAT $\uparrow$ $(0.5)$ is it $(0.5)$ THAT $\uparrow \mathrm{hm}(0.5)$ the people in charge: don't really believe that $\downarrow$ or [they do?

$\mathrm{Na}$ I [think they]

[They do no no no I mean I'm wondering why it has to be reargued every time $\downarrow$ :

I think they really believe it uh (0.5) what I'm not sure is that they put the money into the right place I I (0.5) spoke ((a little bit)) earlier about the three things that matter in education? and I think we've over-emphasized one of them to the expense of the other. We've overemphasized achievement and success, and measuring achievement and success at the expense of what I think matters even more than that and that's engaging young people in something that fascinates and interests them [and]

[what's the difference? because one would imagine that if you engage them in something that fascinates and interests interests $(0.5)$ them that will translate into achievement and [success]

[Absolutely but that's the way to work I I (0.5) agree completely. that we need to start with fascination and interest and lead to achievement uh (0.5) not have our system driven by uh (0.5) achievement and [achievement measures

[I see so by concentrating too much on: MEASURING we are LEACHING things of their fascination is that [what you mean]

[I'm sure about that and if I think back in 40 years in education, the opportunities I had as a teacher in the 1970s and 80s just to pursue: my own, and students' interests was just far greater ((than it is)) now. hh

[You were yes] $\downarrow$

[And I emphasize my own interests because the other thing I think is is missing in this space is the affirmation for teachers actually to be leaders in the classroom and to take. curious young minds into all sorts of places they might not have thought of going and (0.5) the notion that teachers somehow: simply facilitate students' current interests $(0.1)$ to me downplays and $(0.5)$ in a way lowers the status of teaching. Teachers I think have got a wonderful opportunity. uh $(0.5)$ to lead young minds into places they've never ever thought of going before, and $(0.1)$ that's what I loved about teaching

That does seem odd doesn't it THAT we focus on what (0.5) they're interested in already $\downarrow$

Yeah $\downarrow$

As if nothing's ever going to [change]

[Exactly (0.5) that's exactly it and I find that so frustrating we talk about ourselves being facilitators and guides um (0.5) which itself, I think just downgrades the value of that wonderful word teacher. teacher as a leader, so the leader of young minds $\downarrow$ 